\title{
Chronological Development of the Corporate Governance Guidelines in Bangladesh: A Comparative Analysis between CGG- 2012 and CGC-2018
}

\author{
Ahmed Rizvan Hasan ${ }^{1 *}$ Md. Shuvo Howlader ${ }^{2}$ \\ 1. Lecturer, Department of Accounting \& Information Systems, University of Dhaka, Bangladesh \\ 2. Post-graduate Student, Department of Accounting \& Information Systems, University of Dhaka, \\ Bangladesh \\ * E-mail of the corresponding author: rizvan@du.ac.bd
}

\begin{abstract}
In this study, the chronological development of the Corporate Governance Guidelines (CGG) and Corporate Governance Code (CGC) is examined to identify how much the Code has evolved over time. A comparative analysis between the CGG-2012 and CGC-2018 has also been conducted in the study to outline the latest changes and areas of further improvements. The study is exploratory and literature review-based in nature. Hence, contemporary literatures were analyzed along with comparison of the CGG-2012 and CGC-2018 issued by the Bangladesh Securities and Exchange Commission (BSEC). Data was collected from various secondary sources including - corporate governance codes of different countries, research papers, journals, newspaper articles and websites. The study points out that the BSEC has followed a six-year interval pattern in the further development and modification of the corporate governance codes in Bangladesh. Also, it has been found out that in terms of the number of conditions in the code, the CGC-2018 is about 75 percent enhanced than CGG-2012. Previously, CGG2012 was enhanced by more than 150 percent over the first guideline in 2006. CGC-2018 has introduced some crucial governance issues that were not present in the code before but there still remain some areas that are yet to be addressed in the best-practices recommendations.
\end{abstract}

Keywords: Corporate Governance, Nomination and Remuneration Committee, Board of Directors' Committee, Company Website.

DOI: $10.7176 / \mathrm{EJBM} / 12-27-13$

Publication date:September $30^{\text {th }} 2020$

\section{Introduction}

The concept of Corporate Governance (CG) has been around for a few decades in the global context, but it gained prominence in the South Asian region in the late 1990s and early 2000s. This was reflected in the development of 'Desirable Corporate Governance - A Code' by the Confederation of Indian Industry in 1998, in India; also in the passing of the Pakistani code by the Securities \& Exchange Commission of Pakistan in 2002 and the issuance of 'Code of Best Practice on matters related to financial aspects of Corporate Governance' in Sri Lanka, in 1997. Bangladesh also got to see its first corporate governance code in 2004 which was developed by Bangladesh Enterprise Institute (BEI) and it was followed by a guideline issued by the then Securities and Exchange Commission (SEC), a regulatory authority, in 2006. For Bangladesh, corporate governance is no more an emerging issue but one that has traversed more than a decade in the corporate landscape of the country. During this time, guidelines and codes were formulated, devised and improved to promote and uphold better governance in the corporate practices. Bangladesh, being a country that is transitioning to graduation from Least Developed Countries (LDC) status in the near future, requires even better care for ensuring the best possible governance for its corporate citizens.

Following the latest revamp of the Corporate Governance Code, there is dearth of research highlighting the chronological development and a critical comparative analysis between the new code and the one it has superseded. Hence, the objective of this paper is to outline the chronological development that the Corporate Governance Guideline in Bangladesh has gone through. Also, a comparative analysis between the two latest guideline and code has been focused. This study has been conducted to add to the existing body of literature, a comprehensive historical development review of the corporate governance guidelines and code in Bangladesh. Also, this study will act as a reference point that critically examines the CGG 2012 and CGC 2018 and thereby making some suggestions for the future development of the Code. 


\section{Literature Review}

The issue of corporate governance amalgamated momentum in the early part of the first decade of this century due to the occurrences of major corporate failures around the world. Even though the idea of corporate governance was in existence in the second half of the past century, it drew greater concern on the part of the affected stakeholders followed by these big corporate failures. This concern was reflected in the form of developing acts, guidelines, rules and codes to promote the best governance practices and thereby preventing such debacles. The emergence of CG guidelines and Codes is driven by the motive to recoup for imperfections in a country's corporate governance mechanism regarding the protection of shareholders' interests (Aguilera and Cuervo-Cazurra, 2004).

As far as research studies involving the issue of corporate governance in concerned, there are myriad of areas or perspectives from which it has been addressed. In the Bangladeshi context, the strands of researches involving Corporate Governance include - literature review type studies, studies investigating the relationship between firm performance and CG factors, checking of CGG compliance status of various companies/industries, studies revolving around various theories and their bearing on CG phenomenon and so on. Another type of research involves intra and inter country comparative analysis of CG guidelines.

In the South-Asian regional context, it was seen back in the early 2000s that Bangladesh lagged behind its SouthAsian counterparts with regard to corporate governance standards and practices (BEI, 2003; Gillibrand, 2004).

In the Bangladeshi perspective, a critical examination of the changes made in the then existing guidelines from the one issued on 20 February 2006, was made (Biswas, 2012). Areas of further improvement even after the issuance of a new code was sought and suggested in various studies (Biswas, 2012; Rahman \& Khatun, 2017). In another type of study, comparative analysis of the Bangladeshi guidelines and the guidelines of other Asian countries was done (Bhowmik \& Islam, 2013; Das et al., 2018).

\section{Chronological Development of the Corporate Governance Guidelines and Code in Bangladesh}

In Bangladesh, the earliest initiative to develop a guideline for corporate governance was taken back in 2003 by a non-profit, non-political research centre called Bangladesh Enterprise Institute (BEI). As part of this initiative, BEI formed a taskforce comprising prominent individuals from the government, private sector, NGOs and other relevant bodies. Also, the institute undertook a comparative analysis of corporate governance in the context of South Asian region that brought forth the corporate governance scenario at that time. Bangladesh was lagging behind its neighbors with respect to policy formulation regarding corporate governance. The outcome of the BEI's effort was in the form of developing The Code of Corporate Governance for Bangladesh (BEI, 2004).

This private initiative was followed by the issuance of a guideline from the country's capital market regulator then the Securities and Exchange Commission (later renamed as the Bangladesh Securities and Exchange Commission). Though the guideline was not as elaborate as the Code developed by BEI, it was a significant development in the corporate governance scenario in Bangladesh. Later on, the BSEC had improved and extended its guideline after every six years. The latest development was in the form of CGC 2018 that covers greater areas of governance. New areas and provisions have been devised in order to strengthen the governance practices of the corporations.

The major developments in the country's corporate governance policy formulation (SEC, 2006; SEC, 2012; BSEC, 2018) are summarized in Table 1.

Table 1: Chronological Development of CGG and CGC in Bangladesh.

\begin{tabular}{|l|l|}
\hline August, 2003 & Formation of the Taskforce on Corporate Governance \\
\hline March, 2004 & $\begin{array}{l}\text { Publishing of The Code of Corporate Governance for Bangladesh, Principles \& } \\
\text { Guidelines for Best Practices in the Private Sector, Financial Institutions, State- } \\
\text { Owned Enterprises \& Non-Governmental Organizations. }\end{array}$ \\
\hline February, 2006 & Issuance of Corporate Governance Guideline (CGG) 2006 \\
\hline August, 2012 & Issuance of Corporate Governance Guideline (CGG) 2012 \\
\hline June, 2018 & Issuance of Corporate Governance Code (CGC) 2018 \\
\hline
\end{tabular}

In Table 2, information regarding the issuance of subsequent CGG and CGC by the SEC (later BSEC) has been compiled. 
Table 2: CGG and CGC issued by SEC/BSEC and their reference.

\begin{tabular}{|c|c|c|c|c|c|}
\hline $\begin{array}{l}\text { Notification } \\
\text { Date }\end{array}$ & Notification No. & $\begin{array}{c}\text { Date of } \\
\text { Gazette } \\
\text { Publishing }\end{array}$ & $\begin{array}{c}\text { Notification/order } \\
\text { that is } \\
\text { repealed/superseded } \\
\text { by it }\end{array}$ & $\begin{array}{c}\text { To be Complied } \\
\text { with by }\end{array}$ & Amendment \\
\hline $\begin{array}{l}\text { Notification } \\
\text { dated } 20 \\
\text { February, } \\
2006\end{array}$ & $\begin{array}{c}\text { Notification No. } \\
\text { SEC/CMRRCD/2006- } \\
\text { 158/Admin/02-08 }\end{array}$ & $\begin{array}{c}\text { Gazette } \\
\text { dated } 26 \\
\text { April, } 2006\end{array}$ & $\begin{array}{c}\text { Order No. } \\
\text { SEC/CMRRCD/2006- } \\
\text { 158/Admin/02-06 }\end{array}$ & $\begin{array}{l}\text { Disclosure of } \\
\text { Compliance } \\
\text { Status was } \\
\text { mandatory and } \\
\text { was to be } \\
\text { reported in the } \\
\text { Annual Reports } \\
\text { starting from FY } \\
\text { 2006-07 but } \\
\text { Compliance to } \\
\text { the Guidelines } \\
\text { was not } \\
\text { mandatory as the } \\
\text { basis was } \\
\text { 'Comply or } \\
\text { Explain'. }\end{array}$ & None \\
\hline $\begin{array}{c}\text { Notification } \\
\text { dated } 07 \\
\text { August, } \\
2012\end{array}$ & $\begin{array}{c}\text { Notification No. } \\
\text { SEC/CMRRCD/2006- } \\
\text { 158/134/Admin/44 }\end{array}$ & $\begin{array}{c}\text { Gazette } \\
\text { dated } 30 \\
\text { August, } \\
2012\end{array}$ & $\begin{array}{l}\text { Notification No. } \\
\text { SEC/CMRRCD/2006- } \\
\text { 158/Admin/02-08 }\end{array}$ & $\begin{array}{c}31 \text { December } \\
2012\end{array}$ & $\begin{array}{c}\text { Once: } \\
\text { Notification } \\
\text { dated } 21 \text { July, } \\
\text { 2013, Gazette } \\
\text { dated } 20 \\
\text { August, 2013. }\end{array}$ \\
\hline $\begin{array}{l}\text { Notification } \\
\text { dated } 3 \text { June, } \\
2018 \\
\end{array}$ & $\begin{array}{c}\text { Notification No. } \\
\text { BSEC/CMRRCD/2006- } \\
\text { 158/207/Admin/80 }\end{array}$ & $\begin{array}{c}\text { Gazette } \\
\text { dated } 10 \\
\text { June, } 2018 \\
\end{array}$ & $\begin{array}{l}\text { Notification No. } \\
\text { SEC/CMRRCD/2006- } \\
\text { 158/134/Admin/44 }\end{array}$ & $\begin{array}{c}31 \text { December } \\
2018\end{array}$ & None so far \\
\hline
\end{tabular}

\section{Comparison of the CGG(s) and CGC in Bangladesh}

A comparative analysis of the CGG and CGC in Bangladesh is aimed at finding out the recent developments in the best-practices recommendations. Starting from 2006, the corporate governance guideline formulated by the Commission has evolved over more than a decade. The best-practices recommendations had covered more and more areas as time progressed. In Table 3, a side-by-side comparison is done to show the structure of the guideline(s) and code, separated by six years.

\subsection{Structure of the Guideline(s) and Code}

Table 3: Structure of the Guideline(s) and Code.

\begin{tabular}{|l|l|l|}
\hline \multicolumn{1}{|c|}{ CGG-2006 } & \multicolumn{1}{|c|}{ CGG-2012 } & \multicolumn{1}{c|}{ CGC-2018 } \\
\hline $\begin{array}{l}\text { Comply or Explain Basis } \\
\text { (As per condition No. 5) }\end{array}$ & $\begin{array}{l}\text { Comply Basis (As per } \\
\text { condition No. 7) }\end{array}$ & $\begin{array}{l}\text { Comply Basis (As per condition No. 9) } \\
\text { No. of Broad Heads }-9 \text { (3 new heads; } \\
\text { No. of Broad Heads - 5 }\end{array}$ \\
$\begin{array}{l}\text { No. of Broad Heads }-7 \\
\text { previous two heads got combined into one) }\end{array}$ \\
$\begin{array}{l}\text { No. of Conditions }-37 \\
\text { No. of Conditions - 166 (Fully new 62, also } \\
\text { No. of Conditions }-95\end{array}$ & $\begin{array}{l}\text { previous 4 conditions have been split up in 13) } \\
\text { No. of Annexure - 03 }\end{array}$ \\
\hline
\end{tabular}

\subsection{Broad Areas Covered in the Guideline(s) and Code}

The broad areas within the guideline and code have changed greatly in the recent development. Some areas were merged whereas some new areas were introduced for greater addressing of governance issues. Table 4 depicts the gradual change of broad areas used in the guideline(s) and code. 
Table 4: Broad Areas covered in the Guideline(s) and Code over time.

\begin{tabular}{|c|c|c|c|c|}
\hline CGG-2006 & CGG-2012 & Change & CGC-2018 & Change \\
\hline $\begin{array}{l}\text { 1. Board of } \\
\text { Directors }\end{array}$ & 1. Board of Directors & None & 1. Board of Directors & None \\
\hline $\begin{array}{l}\text { 2. Chief Financial } \\
\text { Officer (CFO), } \\
\text { Head of Internal } \\
\text { Audit and Company } \\
\text { Secretary }\end{array}$ & $\begin{array}{l}\text { 2. Chief Financial } \\
\text { Officer (CFO), Head of } \\
\text { Internal Audit and } \\
\text { Company Secretary } \\
\text { (CS) }\end{array}$ & None & $\begin{array}{l}\text { 2. Governance of Board of } \\
\text { Directors of Subsidiary } \\
\text { Company }\end{array}$ & $\begin{array}{l}\text { Numbering } \\
\text { of head } \\
\text { changed } \\
\text { from } 5 \text { to } 2 .\end{array}$ \\
\hline 3. Audit Committee & 3. Audit Committee & None & $\begin{array}{c}\text { 3. Managing Director } \\
\text { (MD) or Chief Executive } \\
\text { Officer (CEO), Chief } \\
\text { Financial Officer (CFO), } \\
\text { Head of Internal Audit } \\
\text { and Compliance (HIAC) } \\
\text { and Company Secretary } \\
\text { (CS) }\end{array}$ & $\begin{array}{l}\text { Numbering } \\
\text { of head got } \\
\text { changed. } \\
\text { Previous } \\
\text { heads No. } 2 \\
\text { and No. } 6 \\
\text { got } \\
\text { combined. }\end{array}$ \\
\hline $\begin{array}{c}4 . \\
\text { External/Statutory } \\
\text { Auditors } \\
\end{array}$ & $\begin{array}{l}\text { 4. External/Statutory } \\
\text { Auditors }\end{array}$ & None & $\begin{array}{l}\text { 4. Board of Directors' } \\
\text { Committee }\end{array}$ & New \\
\hline- & 5. Subsidiary Company & New & 5. Audit Committee & $\begin{array}{l}\text { Numbering } \\
\text { of head } \\
\text { changed } \\
\text { from } 3 \text { to } 5 .\end{array}$ \\
\hline- & $\begin{array}{l}\text { 6. Duties of Chief } \\
\text { Executive Officer } \\
\text { (CEO) And Chief } \\
\text { Financial Officer } \\
\text { (CFO) } \\
\end{array}$ & New & $\begin{array}{l}\text { 6. Nomination and } \\
\text { Remuneration Committee } \\
\text { (NRC) }\end{array}$ & New \\
\hline- & - & - & $\begin{array}{c}\text { 7. External or Statutory } \\
\text { Auditors }\end{array}$ & $\begin{array}{l}\text { Numbering } \\
\text { of head } \\
\text { changed } \\
\text { from } 4 \text { to } 7 .\end{array}$ \\
\hline- & - & - & $\begin{array}{l}\text { 8. Maintaining a website } \\
\text { by the Company. }\end{array}$ & New \\
\hline $\begin{array}{l}\text { 5. Reporting the } \\
\text { Compliance in the } \\
\text { Director's Report }\end{array}$ & $\begin{array}{l}\text { 7. Reporting and } \\
\text { Compliance of } \\
\text { Corporate Governance }\end{array}$ & $\begin{array}{l}\text { Numbering } \\
\text { of head } \\
\text { changed } \\
\text { from } 5 \text { to } \\
7 .\end{array}$ & $\begin{array}{c}\text { 9. Reporting and } \\
\text { Compliance of Corporate } \\
\text { Governance. }\end{array}$ & $\begin{array}{l}\text { Numbering } \\
\text { of head } \\
\text { changed } \\
\text { from } 7 \text { to } 9 .\end{array}$ \\
\hline
\end{tabular}

\subsection{Comparative Analysis between the CGG of 2012 and the CGC of 2018}

In this section, a provision-by-provision comparison between the CGG-2012 and CGC-2018, has been made. In case of some provisions, only the Condition Number $(\mathrm{CN})$ has changed whereas in some cases a totally new provision has been introduced. Also, there are instances where amendments have been made in some existing provisions. Finally, some provisions remained unchanged across the guidelines. The 'new' and 'amended' provisions are presented in tabular format over this section of the paper, in order to present the comparative picture.

\subsubsection{Board of Directors}

In the CGC 2018, under this heading, there are 69 conditions, of which, 16 conditions are totally new (Table 5, Panel A) and 17 conditions are amended from the CGG 2012 (Table 5, Panel B). 
Table 5: Board of Directors

Panel A: New Conditions

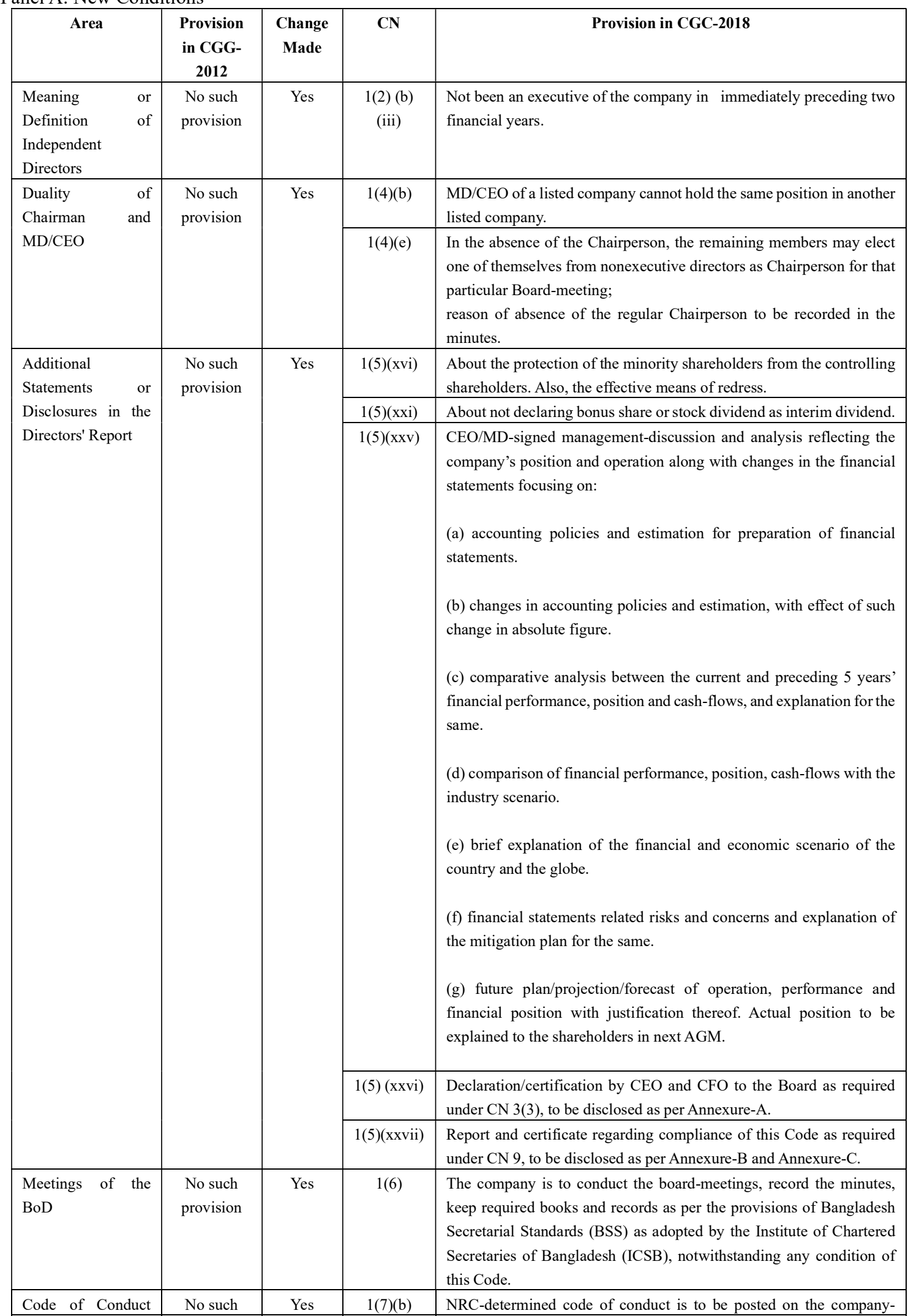




\begin{tabular}{|l|l|l|l|}
\hline $\begin{array}{l}\text { for the Board } \\
\text { Members }\end{array}$ & provision. & & $\begin{array}{l}\text { website including, among others, prudent conduct and behavior; } \\
\text { confidentiality; conflict of interest; compliance with laws, rules and } \\
\text { regulations; prohibition of insider trading; relationship with } \\
\text { environment, employees, customers and suppliers; and independency. }\end{array}$ \\
\hline
\end{tabular}

Panel B: Amended Conditions

\begin{tabular}{|c|c|c|c|c|c|}
\hline Area & $\mathbf{C N}$ & Provision in CGG-2012 & $\begin{array}{c}\text { Chang } \\
\text { e } \\
\text { Made }\end{array}$ & $\mathrm{CN}$ & Provision in CGC-2018 \\
\hline $\begin{array}{l}\text { Number of } \\
\text { Independent } \\
\text { Directors (ID) }\end{array}$ & 1.2 (i) & $\begin{array}{l}\text { No direction was given } \\
\text { regarding fraction. }\end{array}$ & Yes & $1(2)(a)$ & $\begin{array}{l}\text { Fraction shall be considered to the next } \\
\text { integer or whole number. }\end{array}$ \\
\hline \multirow[t]{6}{*}{$\begin{array}{l}\text { Meaning/Definiti } \\
\text { on of IDs }\end{array}$} & $\begin{array}{l}1.2 \text { (ii) } \\
\text { b) }\end{array}$ & $\begin{array}{l}\text { - Not a sponsor of the } \\
\text { company } \\
\text { Not connected with } \\
\text { company's any } \\
\text { sponsor/director/shareho } \\
\text { lder holding one percent } \\
\text { ( } 1 \% \text { ) or more shares of } \\
\text { the total paid-up shares } \\
\text { of the company on the } \\
\text { basis of family } \\
\text { relationship. } \\
\text { Family members also } \\
\text { should not hold above } \\
\text { mentioned shares in the } \\
\text { company. }\end{array}$ & \multirow[t]{6}{*}{ Yes } & $\begin{array}{c}\text { 1(2)(b)(ii } \\
\text { ) }\end{array}$ & $\begin{array}{l}\text { With the previous categories of connections, } \\
\text { the followings have been added: } \\
\text { - Not connected with the company's } \\
\text { nominated director/any of its } \\
\text { associates/sister concerns/subsidiaries } \\
\text { and parents/holding entities.... }\end{array}$ \\
\hline & $\begin{array}{l}1.2 \text { (ii) } \\
\text { d) }\end{array}$ & $\begin{array}{l}\text { Not a } \\
\text { member/director/officer } \\
\text { of any stock exchange. }\end{array}$ & & $\begin{array}{l}\text { 1(2) (b) } \\
\text { (v) }\end{array}$ & $\begin{array}{l}\text { With the previous categories, the following } \\
\text { has been added: } \\
\text { - Not a TREC (Trading Right Entitlement } \\
\text { Certificate) holder. }\end{array}$ \\
\hline & $\begin{array}{l}1.2 \text { (ii) } \\
\text { e) }\end{array}$ & $\begin{array}{l}\text { Not a shareholder, } \\
\text { director/officer of any } \\
\text { member of stock } \\
\text { exchange/an } \\
\text { intermediary of the } \\
\text { capital market. }\end{array}$ & & $\begin{array}{l}\text { 1(2) (b) } \\
\text { (vi) }\end{array}$ & $\begin{array}{l}\text { - Not a shareholder, director excepting } \\
\text { independent director/officer of any } \\
\text { member / TREC holder of stock } \\
\text { exchange / an intermediary of the } \\
\text { capital market. }\end{array}$ \\
\hline & $\begin{array}{l}1.2 \text { (ii) } \\
\text { f) }\end{array}$ & $\begin{array}{l}\text { - Not a partner/an } \\
\text { executive/was not a } \\
\text { partner or an executive } \\
\text { during the preceding } 3 \\
\text { (three) years of the } \\
\text { concerned company's } \\
\text { statutory audit firm. }\end{array}$ & & $\begin{array}{l}\text { 1(2) (b) } \\
\text { (vii) }\end{array}$ & $\begin{array}{l}\text { Following addition to existing provision has } \\
\text { been made: } \\
\text { - ..or audit firm engaged in internal audit } \\
\text { services/audit firm conducting special } \\
\text { audit/ professional certifying } \\
\text { compliance of CGC. }\end{array}$ \\
\hline & $\begin{array}{c}1.2 \text { (ii) } \\
\text { g) }\end{array}$ & $\begin{array}{l}\text { Not an independent director in } \\
\text { more than } 3 \text { listed companies. }\end{array}$ & & $\begin{array}{l}1(2)(b) \\
\text { (viii) }\end{array}$ & $\begin{array}{l}\text { The number is increased to 'not more than } 5 \text { ' } \\
\text { now. }\end{array}$ \\
\hline & $\begin{array}{l}1.2 \text { (ii) } \\
\text { h) }\end{array}$ & $\begin{array}{l}\text { Not been convicted by a court } \\
\text { of competent jurisdiction as a } \\
\text { defaulter in payment of any } \\
\text { loan to a bank or a Non-Bank } \\
\text { Financial Institution (NBFI). }\end{array}$ & & $\begin{array}{l}1(2)(\mathrm{b}) \\
(\mathrm{ix})\end{array}$ & $\begin{array}{l}\text { Following words have been added after 'any } \\
\text { loan' to enhance the definition: 'or any } \\
\text { advance'. }\end{array}$ \\
\hline Tenure of ID & $1.2(\mathrm{vi})$ & $\begin{array}{l}\text { Tenure of an independent } \\
\text { director shall be for a period of } \\
3 \text { (three) years. Extendable for } \\
1 \text { term only. }\end{array}$ & Yes & $1(2)(e)$ & $\begin{array}{l}\text { In addition to the previous provision, the } \\
\text { following extension has been added under the } \\
\text { condition: }\end{array}$ \\
\hline
\end{tabular}




\begin{tabular}{|c|c|c|c|c|c|}
\hline & & & & & $\begin{array}{l}\text { - a former independent director may be } \\
\text { considered for reappointment for } \\
\text { another tenure after a time gap of one } \\
\text { tenure, i.e., three years from his or her } \\
\text { completion of consecutive two tenures } \\
\text { [i.e. six years]. } \\
\text { Also, the ID shall not be subject to } \\
\text { retirement by rotation as per the } \\
\text { Companies Act, } 1994 \text {. } \\
\text { Any partial term of tenure shall be } \\
\text { deemed to be a full tenure. }\end{array}$ \\
\hline \multirow[t]{4}{*}{$\begin{array}{l}\text { Qualifications of } \\
\text { the ID }\end{array}$} & 1.3 (i) & $\begin{array}{l}\text { ID shall be a knowledgeable } \\
\text { individual with integrity who } \\
\text { is able to ensure compliance } \\
\text { with financial, regulatory and } \\
\text { corporate laws and can make } \\
\text { meaningful contribution to } \\
\text { business. }\end{array}$ & \multirow[t]{4}{*}{ Yes } & 1(3)(a) & $\begin{array}{l}\text { Kept the provision same as before with some } \\
\text { modification in wording: } \\
\text {...able to ensure compliance with financial } \\
\text { laws, regulatory requirements and corporate } \\
\underline{\text { laws }} . . .\end{array}$ \\
\hline & 1.3 (ii) & $\begin{array}{l}\text { The person should be a } \\
\text { Business Leader/Corporate } \\
\text { Leader/Bureaucrat/University } \\
\text { Teacher with } \\
\text { Economics/Business } \\
\text { Studies/Law } \\
\text { background/Professionals like } \\
\text { Chartered Accountants, Cost } \\
\text { \& Management Accountants, } \\
\text { Chartered Secretaries. }\end{array}$ & & $\begin{array}{c}\text { 1(3)(b)(i) } \\
\text { 1(3)(b)(ii } \\
\text { ) } \\
\text { 1(3)(b)(ii } \\
\text { i) } \\
\text { 1(3)(b)(i } \\
\text { v) } \\
1(3)(\mathrm{b})(\mathrm{v} \\
\text { ) }\end{array}$ & $\begin{array}{l}\text { As per the new provision the following people } \\
\text { can be appointed as ID: } \\
\text { - Business Leader } \\
\text { - Corporate Leader } \\
\text { - Former official of } \\
\text { government/statutory/autonomous/regu } \\
\text { latory body } \\
\text { - University teacher } \\
\text { - Advocate Acrartered Accountant/Cost and } \\
\text { Management Accountant/Chartered } \\
\text { Financial Analyst/Chartered Certified } \\
\text { Accountant/Certified } \\
\text { Accountant/Chartered Management } \\
\text { Accountant/Chartered Secretary or } \\
\text { equivalently qualified individual. } \\
\text { Detail qualification requirements for each of } \\
\text { the aforementioned party have also been } \\
\text { added in the provision. }\end{array}$ \\
\hline & 1.3 (ii) & $\begin{array}{l}\text { The ID must have at least } \mathbf{1 2} \\
\text { (twelve) years of corporate } \\
\text { management/professional } \\
\text { experiences. }\end{array}$ & & $1(3)(\mathrm{c})$ & $\begin{array}{l}\text { ID shall have at least } 10 \text { (ten) years of } \\
\text { experiences in any field mentioned in } \mathrm{CN} \\
1(3)(\mathrm{b}) \text {. }\end{array}$ \\
\hline & 1.3 (iii) & $\begin{array}{l}\text { In special cases the mentioned } \\
\text { qualifications may be relaxed } \\
\text { subject to prior approval of the } \\
\text { Commission (i.e. BSEC). }\end{array}$ & & 1(3)(d) & $\begin{array}{l}\text { Kept the provision same as before with some } \\
\text { modification in wording: } \\
\text {...the mentioned qualifications or } \\
\text { experiences may be relaxed.... }\end{array}$ \\
\hline $\begin{array}{l}\text { Duality of } \\
\text { Chairman and } \\
\text { MD/CEO }\end{array}$ & 1.4 & $\begin{array}{l}\text { Chairman shall be elected } \\
\text { from among the directors of } \\
\text { the company. }\end{array}$ & Yes & $1(4)(c)$ & $\begin{array}{l}\text {...shall be elected from among the non- } \\
\text { executive directors of the company. }\end{array}$ \\
\hline \multirow[t]{2}{*}{$\begin{array}{l}\text { Additional } \\
\text { Statements/ } \\
\text { Disclosures in the } \\
\text { Directors' Report }\end{array}$} & 1.5 (iii) & Risks and concerns. & \multirow[t]{2}{*}{ Yes } & 1(5) (iii) & $\begin{array}{l}\text { More specific risk and concern disclosure } \\
\text { required in the form of disclosure on internal } \\
\text { and external risk factors, threat to } \\
\text { sustainability and negative impact on } \\
\text { environment, if any. }\end{array}$ \\
\hline & 1.5 (iv) & $\begin{array}{l}\text { A discussion on Cost of Goods } \\
\text { sold, Gross Profit Margin and } \\
\text { Net Profit Margin }\end{array}$ & & 1(5) (iv) & $\begin{array}{l}\text { Same disclosure is required but only where it } \\
\text { is applicable. }\end{array}$ \\
\hline
\end{tabular}




\begin{tabular}{|c|c|c|c|c|c|}
\hline & $1.5(\mathrm{v})$ & $\begin{array}{l}\text { Discussion on continuity of } \\
\text { any Extra-Ordinary gain or } \\
\text { loss. }\end{array}$ & & $1(5)(v)$ & $\begin{array}{l}\text { Same disclosure is required along with } \\
\text { implications. }\end{array}$ \\
\hline & 1.5 (vi) & $\begin{array}{l}\text { Basis for related party } \\
\text { transactions. } \\
\text { A statement of all related party } \\
\text { transactions in the annual } \\
\text { report. }\end{array}$ & & 1(5) (vi) & $\begin{array}{l}\text { Detailed discussion on related party } \\
\text { transactions. A statement showing amount, } \\
\text { nature of related party, nature of transactions } \\
\text { and basis of transactions of all related party } \\
\text { transactions. }\end{array}$ \\
\hline $\begin{array}{l}\text { Code of Conduct } \\
\text { for the Board } \\
\text { Members }\end{array}$ & $\begin{array}{l}1.2(\mathrm{v}) \\
{[\text { Further }} \\
\text { referenc } \\
\quad \text { e in } \\
6(\text { ii })]\end{array}$ & $\begin{array}{l}\text { Board shall lay down a code of } \\
\text { conduct for all Board } \\
\text { members. } \\
\text { Annual compliance of the code } \\
\text { to be recorded. }\end{array}$ & Yes & $\begin{array}{l}1(7)(\mathrm{a}) \\
{[\text { Further }} \\
\text { reference } \\
\text { in } 3(3)(\mathrm{b}) \\
\text { Annexur } \\
\text { e-A (ii)] }\end{array}$ & $\begin{array}{l}\text { Board shall lay down a code of conduct, based } \\
\text { on the recommendation of the Nomination } \\
\text { and Remuneration Committee (NRC) at } \\
\text { CN. 6, for the Chairperson of the Board, other } \\
\text { board members and Chief Executive Officer } \\
\text { of the company. }\end{array}$ \\
\hline
\end{tabular}

\subsubsection{Governance of Board of Directors of Subsidiary Company}

The governance issues of subsidiary company were dealt in the heading 5 of CGG-2012. In CGC-2018, the heading number has changed, thereby changing the Condition Numbers as well. Apart from this, all the provisions remained the same. Previous CN 5 (i-v) have become present CN 2(a-e).

\subsubsection{Managing Director (MD) or Chief Executive Officer (CEO), Chief Financial Officer (CFO), Head of} Internal Audit and Compliance (HIAC) and Company Secretary (CS)

The contents of this head were discussed under Head No. 2 and 6 in CGG-2012. Now those 2 heads have been merged into the new Head No. 3 of the CGC-2018. Also, the term 'Managing Director (MD)' has been added to the title as equivalent to CEO and 'Head of Internal Audit' has been replaced by 'Head of Internal Audit and Compliance (HIAC)'. The total number of conditions under this head is 10, of which 4 are new (Table 6, Panel A) and 2 are amended (Table 6, Panel B).

Table 6: $\mathrm{MD} / \mathrm{CEO}, \mathrm{CFO}, \mathrm{HIAC}$ and $\mathrm{CS}$

Panel A: New Conditions

\begin{tabular}{|c|c|c|c|l|}
\hline Area & $\begin{array}{l}\text { Provision } \\
\text { in CGG- } \\
\text { 2012 }\end{array}$ & $\begin{array}{l}\text { Change } \\
\text { Made }\end{array}$ & CN & \multicolumn{1}{|c|}{ Provision in CGC-2018 } \\
\hline Appointment & $\begin{array}{l}\text { No such } \\
\text { provision }\end{array}$ & Yes & $3(1)(\mathrm{b})$ & $\begin{array}{l}\text { The positions of MD/CEO, CS, CFO and HIAC are to } \\
\text { be filled by different individuals. }\end{array}$ \\
\cline { 3 - 5 } & $3(1)(\mathrm{c})$ & $\begin{array}{l}\text { The MD or CEO, CS, CFO and HIAC of a listed } \\
\text { company shall not hold any executive position in any } \\
\text { other company simultaneously. }\end{array}$ \\
\cline { 3 - 5 } & $3(1)(\mathrm{e})$ & $\begin{array}{l}\text { Without board-approval as well as immediate } \\
\text { dissemination to the Commission and stock } \\
\text { exchange(s), the MD/CEO, CS, CFO and HIAC cannot } \\
\text { be removed from their position. }\end{array}$ \\
\hline $\begin{array}{l}\text { Duties of } \\
\text { MD or CEO } \\
\text { and CFO. }\end{array}$ & $\begin{array}{l}\text { No such } \\
\text { provision }\end{array}$ & Yes & $3(3)(\mathrm{c})$ & $\begin{array}{l}\text { MD/CEO and CFO certification shall be disclosed in } \\
\text { the Annual Report. }\end{array}$ \\
\hline
\end{tabular}


Panel B: Amended Conditions

\begin{tabular}{|l|c|l|c|c|l|}
\hline \multicolumn{1}{|c|}{ Area } & CN & Provision in CGG-2012 & $\begin{array}{l}\text { Change } \\
\text { Made }\end{array}$ & CN & Provision in CGC-2018 \\
\hline Appointment & 2.1 & $\begin{array}{l}\text { Company shall appoint a } \\
\text { CFO, Y Head of Internal } \\
\text { Audit (Internal Control } \\
\text { and Compliance) and a } \\
\text { CS. }\end{array}$ & $3(1)(a)$ & $\begin{array}{l}\text { Board shall appoint an } \\
\text { MD/CEO, a CS, a CFO and a } \\
\text { HIAC. }\end{array}$ \\
\hline $\begin{array}{l}\text { Requirement } \\
\text { to attend } \\
\text { Board of } \\
\text { Directors' } \\
\text { Meetings }\end{array}$ & 2.2 & $\begin{array}{l}\text { CFO and CS of the } \\
\text { companies shall attend } \\
\text { the meetings of the Board } \\
\text { of Directors, provided } \\
\text { that CFO and/or CS shall } \\
\text { not attend such part of a } \\
\text { meeting of the Board } \\
\text { which involves } \\
\text { consideration of an } \\
\text { agenda item relating to } \\
\text { their personal matters. }\end{array}$ & Yes) & $\begin{array}{l}\text { MD/CEO, CS, CFO and HIAC } \\
\text { of the company shall attend the } \\
\text { meetings of the Board, } \\
\text { provided that the CS, CFO } \\
\text { and/or the HIAC shall not } \\
\text { attend such part... }\end{array}$ \\
\hline
\end{tabular}

\subsubsection{Board of Directors' Committee}

This heading, having 2 conditions in it, is a new addition. One of the conditions is new (Table 7), whereas, the other one could be found with different CN in CGG-2012.

Table 7: New Conditions in Board of Directors' Committee

\begin{tabular}{|c|c|c|c|c|}
\hline Area & Provision in CGG-2012 & $\begin{array}{c}\text { Change } \\
\text { Made }\end{array}$ & $\mathbf{C N}$ & Provision in CGC-2018 \\
\hline $\begin{array}{l}\text { Sub-Committees } \\
\text { of the BoD }\end{array}$ & $\begin{array}{l}\text { No such provision } \\
\text { There was a provision } \\
\text { however, requiring the } \\
\text { company having an } \\
\text { Audit Committee as a } \\
\text { sub-committee of the } \\
\text { Board of Directors } \\
\text { [Reference 3(i)] }\end{array}$ & Yes & $\begin{array}{l}\text { 4(i) } \\
\text { and } \\
\text { (ii) }\end{array}$ & $\begin{array}{l}\text { For ensuring good governance, the } \\
\text { Board shall have at least these sub- } \\
\text { committees: } \\
\text { (i) Audit Committee. } \\
\text { (ii) Nomination and Remuneration } \\
\text { Committee. }\end{array}$ \\
\hline
\end{tabular}

\subsubsection{Audit Committee (AC)}

This head has total 34 conditions under it, of which, 6 are new (Table 8, Panel A) and 9 are amended (Table 8, Panel B). Of these 9 amendments, 2 are mere addition of words.

Table 8: Audit Committee

Panel A: New Conditions

\begin{tabular}{|l|c|c|c|l|}
\hline \multicolumn{1}{|c|}{ Area } & $\begin{array}{c}\text { Provision in } \\
\text { CGG-2012 }\end{array}$ & $\begin{array}{c}\text { Change } \\
\text { Made }\end{array}$ & CN & \multicolumn{1}{|c|}{ Provision in CGC-2018 } \\
\hline $\begin{array}{l}\text { Chairperson } \\
\text { of the AC }\end{array}$ & $\begin{array}{c}\text { No such } \\
\text { provision }\end{array}$ & Yes & $5(3)(\mathrm{b})$ & $\begin{array}{l}\text { In absence of AC-chairperson, the remaining } \\
\text { members may elect one of themselves as } \\
\text { Chairperson for a particular meeting, in that case } \\
\text { there shall be no problem of constituting a quorum } \\
\text { as required under CN. 5(4)(b) and the reason of } \\
\text { absence is to be duly recorded in minutes. }\end{array}$ \\
\hline $\begin{array}{l}\text { Meeting of } \\
\text { the AC }\end{array}$ & $\begin{array}{l}\text { No such } \\
\text { provision }\end{array}$ & Yes & $5(4)(\mathrm{a})$ & $\begin{array}{l}\text { The AC shall conduct at least four meetings in a } \\
\text { financial year. Emergency meeting in addition to } \\
\text { regular meeting may be convened at the request of } \\
\text { any one of the members of the Committee. }\end{array}$ \\
\cline { 2 - 5 } & & 5(4)(b) & AC's meeting-quorum shall be constituted in \\
\hline
\end{tabular}




\begin{tabular}{|c|c|c|c|c|}
\hline & & & & $\begin{array}{l}\text { presence of either two members or two-third of the } \\
\text { members of the Committee, whichever is higher, } \\
\text { where presence of an ID is a must. }\end{array}$ \\
\hline \multirow[t]{3}{*}{ Role of AC } & \multirow[t]{3}{*}{$\begin{array}{l}\text { No such } \\
\text { provision }\end{array}$} & \multirow[t]{3}{*}{ Yes } & $5(5)(e)$ & $\begin{array}{l}\text { Holding meeting with the external/statutory } \\
\text { auditors for review of the annual financial } \\
\text { statements before submission to the Board for } \\
\text { approval/adoption. }\end{array}$ \\
\hline & & & $5(5)(i)$ & $\begin{array}{l}\text { Reviewing the Management's Discussion and } \\
\text { Analysis before disclosing in the Annual Report. }\end{array}$ \\
\hline & & & $5(5)(1)$ & $\begin{array}{l}\text { Overseeing the determination of audit-fees based on } \\
\text { scope and magnitude, level of expertise deployed, } \\
\text { and time required for effective audit. Evaluating the } \\
\text { performance of external auditors. }\end{array}$ \\
\hline
\end{tabular}

Panel B: Amended Conditions

\begin{tabular}{|c|c|c|c|c|c|}
\hline Area & $\mathbf{C N}$ & Provision in CGG-2012 & Change & $\mathbf{C N}$ & Provision in CGC-2018 \\
\hline \multirow[t]{2}{*}{$\begin{array}{l}\text { Constitution } \\
\text { of the } \mathrm{AC}\end{array}$} & 3.1(ii) & $\begin{array}{l}\text { Board of Directors shall } \\
\text { appoint members of the AC } \\
\text { who shall be directors of the } \\
\text { company and shall include } \\
\text { at least } 1 \text { ID. }\end{array}$ & Yes & $5(2)(b)$ & $\begin{array}{l}\text {...who shall be } \underline{\text { non- }} \\
\text { executive directors of the } \\
\text { company } \\
\text { Chairperson of the Board } \\
\text { and shall include at least 1 } \\
\text { ID. }\end{array}$ \\
\hline & 3.1(iii) & $\begin{array}{l}\text { All members of the audit } \\
\text { committee should be } \\
\text { "financially literate" and at } \\
\text { least } 1 \text { member shall have } \\
\text { accounting or related } \\
\text { financial management } \\
\text { experience. } \\
\text { Explanation: The term } \\
\text { "financially literate" means } \\
\text { the ability to read and } \\
\text { understand the financial } \\
\text { statements like Balance } \\
\text { Sheet, Income Statement } \\
\text { and Cash Flow Statement } \\
\text { and a person will be } \\
\text { considered to have } \\
\text { accounting or related } \\
\text { financial management } \\
\text { expertise if (s)he possesses } \\
\text { professional qualification } \\
\text { or Accounting/ Finance } \\
\text { graduate with at least } 12 \\
\text { (twelve) years of corporate } \\
\text { management/professional } \\
\text { experiences. }\end{array}$ & Yes & $5(2)(c)$ & $\begin{array}{l}\text { New provision requires the } \\
\text { experience to be at least } 10 \\
\text { years, with other portions } \\
\text { remaining the same. } \\
\text { In the Explanation, new } \\
\text { names of the financial } \\
\text { statements have been used. } \\
\text { Experience requirement has } \\
\text { been reduced to } 10 \text { years. }\end{array}$ \\
\hline $\begin{array}{l}\text { Chairperson } \\
\text { of the } A C\end{array}$ & 3.2(ii) & $\begin{array}{l}\text { Chairman of the AC shall } \\
\text { remain present in the AGM. }\end{array}$ & Yes & $5(3)(c)$ & $\begin{array}{l}\text { Chairperson of the AC shall } \\
\text { remain present in the AGM. } \\
\text { In absence of AC- } \\
\text { chairperson, any other } \\
\text { member from the AC shall } \\
\text { be selected to be present in } \\
\text { the AGM. Reason of }\end{array}$ \\
\hline
\end{tabular}




\begin{tabular}{|c|c|c|c|c|c|}
\hline & & & & & $\begin{array}{l}\text { absence shall be recorded in } \\
\text { the minutes of the AGM. }\end{array}$ \\
\hline \multirow[t]{3}{*}{ Role of AC } & 3.3 (iii) & $\begin{array}{l}\text { Monitoring Internal } \\
\text { Control Risk management } \\
\text { process. }\end{array}$ & Yes & $5(5)(c)$ & $\begin{array}{l}\text { Monitoring Internal Audit } \\
\text { and Compliance process to } \\
\text { ensure that it is adequately } \\
\text { resourced, including } \\
\text { approval of the Internal } \\
\text { Audit and Compliance Plan } \\
\text { and review of the Internal } \\
\text { Audit and Compliance } \\
\text { Report. }\end{array}$ \\
\hline & 3.3(viii) & $\begin{array}{l}\text { Review statement of } \\
\text { significant related party } \\
\text { transactions } \\
\text { the management. }\end{array}$ & & $5(5)(j)$ & $\begin{array}{l}\text { Used the word 'All' in } \\
\text { place of 'Significant'. }\end{array}$ \\
\hline & $3.3(\mathrm{x})$ & $\begin{array}{l}\text { Quarterly reporting by the } \\
\text { Company to the AC about } \\
\text { the uses/applications of } \\
\text { funds raised through } \\
\text { IPO/RPO/Rights Issue. } \\
\text { This disclosure is to be } \\
\text { made as part of the } \\
\text { quarterly financial } \\
\text { declaration and to be shown } \\
\text { by major category e.g. } \\
\text { capital expenditure, sales } \\
\text { and marketing etc. } \\
\text { Annual reporting in the } \\
\text { form of a statement of funds } \\
\text { utilized for the purposes } \\
\text { other than those stated in } \\
\text { the offer } \\
\text { document/prospectus. }\end{array}$ & & $5(5)(\mathrm{m})$ & $\begin{array}{l}\text { Overseeing whether the } \\
\text { proceeds raised through } \\
\text { Initial Public Offering } \\
\text { (IPO) or Repeat Public } \\
\text { Offering (RPO) or Rights } \\
\text { Share Offer have been } \\
\text { utilized as per the purposes } \\
\text { stated in relevant offer } \\
\text { document/prospectus } \\
\text { approved by } \\
\text { Commission. } \\
\text { Quarterly reporting } \\
\text { requirement remains the } \\
\text { same as before. } \\
\text { Annual reporting is to be } \\
\text { published in the Annual } \\
\text { Report along with the } \\
\text { comments of AC. }\end{array}$ \\
\hline \multirow[t]{3}{*}{$\begin{array}{l}\text { Immediate } \\
\text { reporting by } \\
\text { AC to the } \\
\text { Board on } \\
\text { mentioned } \\
\text { findings, if } \\
\text { any }\end{array}$} & $\begin{array}{l}\text { 3.4.1(ii) } \\
\text { b) }\end{array}$ & $\begin{array}{l}\text { Suspected/presumed fraud } \\
\text { or irregularity or material } \\
\text { defect in the internal } \\
\text { control system. }\end{array}$ & \multirow[t]{3}{*}{ Yes } & $\begin{array}{l}5(6)(a) \\
\text { (ii)(b) }\end{array}$ & $\begin{array}{l}\text { Suspected/presumed fraud } \\
\text { or irregularity or material } \\
\text { defect identified in the } \\
\text { internal audit and } \\
\text { compliance process or in } \\
\text { the financial statements. }\end{array}$ \\
\hline & $\begin{array}{l}\text { 3.4.1(ii) } \\
\text { c) }\end{array}$ & $\begin{array}{l}\text { Suspected infringement of } \\
\text { laws, including securities } \\
\text { related laws, rules and } \\
\text { regulations. }\end{array}$ & & $\begin{array}{l}5(6)(a) \\
\text { (ii)(c) }\end{array}$ & $\begin{array}{l}\begin{array}{l}\text { Suspected infringement of } \\
\text { laws, }\end{array} \\
\text { compliances } \\
\text { securities related laws, } \\
\text { rules and regulations. }\end{array}$ \\
\hline & $\begin{array}{l}\text { 3.4.1(ii) } \\
\text { d) }\end{array}$ & $\begin{array}{l}\text { Any other matter which } \\
\text { shall be disclosed to the } \\
\text { Board of Directors } \\
\text { immediately. }\end{array}$ & & $\begin{array}{l}5(6)(a) \\
\text { (ii)(d) }\end{array}$ & $\begin{array}{l}\text { Any other matter which the } \\
\text { Audit Committee deems } \\
\text { necessary shall be } \\
\text { disclosed to the Board } \\
\text { immediately. }\end{array}$ \\
\hline
\end{tabular}


4.3.6 Nomination and Remuneration Committee (NRC):

This is a completely new head under the CGC 2018 that has 29 new conditions (Table 9) structured under 5 subpoints.

Table 9: New Conditions in Nomination and Remuneration Committee (NRC)

\begin{tabular}{|c|c|c|c|c|}
\hline Area & $\begin{array}{c}\text { Provision in } \\
\text { CGG-2012 } \\
\end{array}$ & $\begin{array}{c}\text { Change } \\
\text { Made }\end{array}$ & $\mathbf{C N}$ & Provision in CGC-2018 \\
\hline \multirow[t]{3}{*}{$\begin{array}{l}\text { Responsibility } \\
\text { to the Board }\end{array}$} & \multirow[t]{3}{*}{$\begin{array}{l}\text { No such } \\
\text { provision }\end{array}$} & \multirow[t]{3}{*}{ Yes } & $6(1)(a)$ & $\begin{array}{l}\text { The company shall have a Nomination and } \\
\text { Remuneration Committee (NRC) as a sub- } \\
\text { committee of the Board. }\end{array}$ \\
\hline & & & $6(1)(b)$ & $\begin{array}{l}\text { NRC shall assist the Board in formulating the } \\
\text { nomination criteria/policy for establishing } \\
\text { qualifications, positive attributes, experiences, } \\
\text { independence and remuneration of directors and } \\
\text { top-level executive. }\end{array}$ \\
\hline & & & $6(1)(c)$ & $\begin{array}{l}\text { Terms of Reference (ToR) of the NRC shall be } \\
\text { clearly set forth in writing covering areas stated } \\
\text { at CN. } 6(5)(\mathrm{b}) \text {. }\end{array}$ \\
\hline \multirow[t]{9}{*}{$\begin{array}{l}\text { Constitution } \\
\text { of the NRC }\end{array}$} & \multirow[t]{9}{*}{$\begin{array}{l}\text { No such } \\
\text { provision }\end{array}$} & \multirow[t]{9}{*}{ Yes } & $6(2)(a)$ & $\begin{array}{l}\text { NRC shall comprise of at least three members } \\
\text { including an ID. }\end{array}$ \\
\hline & & & $6(2)(b)$ & $\begin{array}{l}\text { All members of NRC shall be non-executive } \\
\text { directors. }\end{array}$ \\
\hline & & & $6(2)(c)$ & $\begin{array}{l}\text { NRC-members shall be nominated and appointed } \\
\text { by Board. }\end{array}$ \\
\hline & & & $6(2)(d)$ & $\begin{array}{l}\text { Board shall have authority to remove and appoint } \\
\text { any member of NRC. }\end{array}$ \\
\hline & & & $6(2)(e)$ & $\begin{array}{l}\text { In case of death, resignation, disqualification, or } \\
\text { removal of any member of NRC, or in any other } \\
\text { cases of vacancies, Board shall fill the vacancy } \\
\text { within } 180 \text { days of occurring such vacancy. }\end{array}$ \\
\hline & & & $6(2)(\mathrm{f})$ & $\begin{array}{l}\text { If felt necessary, NRC-chairperson may } \\
\text { appoint/co-opt any external expert and/or } \\
\text { member(s) of staff to the Committee as advisor } \\
\text { who shall be non-voting member. }\end{array}$ \\
\hline & & & $6(2)(g)$ & $\begin{array}{l}\text { Company Secretary shall act as the NRC- } \\
\text { secretary. }\end{array}$ \\
\hline & & & $6(2)(h)$ & $\begin{array}{l}\text { NRC meeting-quorum shall not constitute } \\
\text { without attendance of at least an ID. }\end{array}$ \\
\hline & & & $6(2)(\mathrm{i})$ & $\begin{array}{l}\text { No NRC-member shall receive, either directly or } \\
\text { indirectly, any remuneration for any } \\
\text { advisory/consultancy role or otherwise, other } \\
\text { than Director's fees/honorarium from the } \\
\text { company. }\end{array}$ \\
\hline \multirow[t]{3}{*}{$\begin{array}{l}\text { Chairperson of } \\
\text { the NRC }\end{array}$} & \multirow[t]{3}{*}{$\begin{array}{l}\text { No such } \\
\text { provision }\end{array}$} & \multirow[t]{3}{*}{ Yes } & $6(3)(a)$ & $\begin{array}{l}\text { Board shall select one member of the NRC to be } \\
\text { Chairperson of the Committee, who shall be an } \\
\text { ID. }\end{array}$ \\
\hline & & & $6(3)(b)$ & $\begin{array}{l}\text { In absence of NRC-chairperson, remaining } \\
\text { members may elect one of themselves as } \\
\text { Chairperson for a particular meeting. Reason of } \\
\text { absence of the regular Chairperson shall be duly } \\
\text { recorded in minutes. }\end{array}$ \\
\hline & & & $6(3)(c)$ & $\begin{array}{l}\text { NRC-chairperson shall remain present at the } \\
\text { AGM to answer queries of the shareholders. In } \\
\text { case of his/her absence, any other NRC-member } \\
\text { shall be selected to attend the AGM in this regard. } \\
\text { Reason for absence of NRC-chairperson shall be } \\
\text { recorded in AGM-minutes. }\end{array}$ \\
\hline
\end{tabular}




\begin{tabular}{|c|c|c|c|c|}
\hline \multirow[t]{4}{*}{$\begin{array}{l}\text { Meeting of the } \\
\text { NRC }\end{array}$} & \multirow[t]{4}{*}{$\begin{array}{l}\text { No such } \\
\text { provision }\end{array}$} & \multirow[t]{4}{*}{ Yes } & $6(4)(a)$ & $\begin{array}{l}\text { NRC shall conduct at least one meeting in a } \\
\text { financial year. }\end{array}$ \\
\hline & & & $6(4)(b)$ & $\begin{array}{l}\text { NRC-chairperson may convene any emergency } \\
\text { meeting upon request by any NRC-member. }\end{array}$ \\
\hline & & & $6(4)(c)$ & $\begin{array}{l}\text { NRC-meeting quorum shall be established in the } \\
\text { presence of either two or two-thirds of the NRC- } \\
\text { members, whichever is higher, where an ID is a } \\
\text { must under CN. } 6(2)(\mathrm{h}) \text {. }\end{array}$ \\
\hline & & & $6(4)(d)$ & $\begin{array}{l}\text { Each NRC meeting proceedings shall be duly } \\
\text { recorded in the minutes. Such minutes shall be } \\
\text { confirmed in the next NRC-meeting. }\end{array}$ \\
\hline $\begin{array}{l}\text { Independence } \\
\& \\
\text { Accountability } \\
\text { of NRC }\end{array}$ & $\begin{array}{l}\text { No such } \\
\text { provision }\end{array}$ & Yes & $6(5)(a)$ & \begin{tabular}{llll} 
NRC shall be & \multicolumn{2}{c}{ independent } & and \\
responsible/accountable & to & Board & and \\
shareholders. & & & \\
\end{tabular} \\
\hline \multirow[t]{10}{*}{$\begin{array}{l}\text { Report to the } \\
\text { Board }\end{array}$} & \multirow[t]{10}{*}{$\begin{array}{l}\text { No such } \\
\text { provision }\end{array}$} & \multirow[t]{10}{*}{ Yes } & $6(5)(b)$ & $\begin{array}{l}\text { NRC shall oversee, among others, matters } \\
\text { mentioned in this condition and make report with } \\
\text { recommendation to the Board. }\end{array}$ \\
\hline & & & $\begin{array}{l}6(5)(b)( \\
\text { i) }\end{array}$ & $\begin{array}{l}\text { Formulating the criteria for determining } \\
\text { qualifications, positive attributes and } \\
\text { independence of a director and recommending a } \\
\text { policy to the Board, relating to the remuneration } \\
\text { of the directors, top level executive, considering } \\
\text { the provisions in } 6(5)(\mathrm{b})(\mathrm{i})(\mathrm{a}-\mathrm{c}) \text {. }\end{array}$ \\
\hline & & & $\begin{array}{l}6(5)(b)( \\
\text { i)(a) }\end{array}$ & $\begin{array}{l}\text { Level and composition of remuneration is } \\
\text { reasonable and sufficient to attract, retain and } \\
\text { motivate suitable directors to run company } \\
\text { successfully. }\end{array}$ \\
\hline & & & $\begin{array}{l}6(5)(b)( \\
\text { i)(b) }\end{array}$ & $\begin{array}{l}\text { Relationship of remuneration to performance is } \\
\text { clear and meets appropriate performance- } \\
\text { benchmarks. }\end{array}$ \\
\hline & & & $\begin{array}{l}6(5)(b)( \\
\text { i)(c) }\end{array}$ & $\begin{array}{l}\text { Remuneration to directors, top level executive } \\
\text { involves a balance between fixed and incentive- } \\
\text { pay reflecting short and long-term performance } \\
\text { objectives appropriate to company and its goals. }\end{array}$ \\
\hline & & & $\begin{array}{l}6(5)(b)( \\
\text { ii) }\end{array}$ & $\begin{array}{l}\text { Devising policy on Board's diversity taking into } \\
\text { consideration age, gender, experience, ethnicity, } \\
\text { educational background and nationality. }\end{array}$ \\
\hline & & & $\begin{array}{l}6(5)(b)( \\
\text { iii) }\end{array}$ & $\begin{array}{l}\text { Identifying persons qualified to become directors } \\
\text { and who may be appointed in top level executive } \\
\text { position in accordance with the criteria. } \\
\text { Recommending their appointment and removal, } \\
\text { to the Board. }\end{array}$ \\
\hline & & & $\begin{array}{l}6(5)(b)( \\
\text { iv) }\end{array}$ & $\begin{array}{l}\text { Formulating performance evaluation-criteria for } \\
\text { IDs and Board. }\end{array}$ \\
\hline & & & $\begin{array}{l}6(5)(b)( \\
v)\end{array}$ & $\begin{array}{l}\text { Identifying company's needs for employees at } \\
\text { different levels. Determining selection, } \\
\text { transfer/replacement and promotion criteria. }\end{array}$ \\
\hline & & & $\begin{array}{l}6(5)(b)( \\
\text { vi) }\end{array}$ & $\begin{array}{l}\text { Developing, recommending and reviewing } \\
\text { annually the company's HR and training policies. }\end{array}$ \\
\hline $\begin{array}{l}\text { Disclosure in } \\
\text { Annual Report }\end{array}$ & $\begin{array}{l}\text { No such } \\
\text { provision }\end{array}$ & Yes & $6(5)(c)$ & $\begin{array}{l}\text { NRC's nomination and remuneration policy, } \\
\text { assessment criteria and activities during the year } \\
\text { should be disclosed in annual report. }\end{array}$ \\
\hline
\end{tabular}

\subsubsection{External or Statutory Auditors}

This head has 11 conditions from which 3 are new (Table 10, Panel A) and 2 are amended (Table 10, Panel B). 
Table 10: External or Statutory Auditors

Panel A: New Conditions

\begin{tabular}{|c|c|c|c|c|}
\hline Area & $\begin{array}{c}\text { Provision in } \\
\text { CGG-2012 }\end{array}$ & $\begin{array}{c}\text { Change } \\
\text { Made }\end{array}$ & $\mathbf{C N}$ & Provision in CGC-2018 \\
\hline \multirow{2}{*}{$\begin{array}{l}\text { Non-permissible } \\
\text { services for the } \\
\text { external/statutory } \\
\text { auditors. }\end{array}$} & \multirow[t]{2}{*}{$\begin{array}{l}\text { No such } \\
\text { provision }\end{array}$} & \multirow[t]{2}{*}{ Yes } & $7(1)$ (viii) & $\begin{array}{l}\text { Audit/certification services on compliance } \\
\text { of corporate governance as required under } \\
\text { CN. 9(1). }\end{array}$ \\
\hline & & & 7(1)(ix) & $\begin{array}{l}\text { Any other service that creates conflict of } \\
\text { interest. }\end{array}$ \\
\hline $\begin{array}{l}\text { External/Statutory } \\
\text { Auditors' presence } \\
\text { in the Shareholders' } \\
\text { Meeting }\end{array}$ & $\begin{array}{l}\text { No such } \\
\text { provision }\end{array}$ & Yes & $7(3)$ & $\begin{array}{l}\text { Representative of external/statutory } \\
\text { auditors shall remain present in the } \\
\text { Shareholders' Meeting (AGM or } \\
\text { Extraordinary General Meeting) to answer } \\
\text { the queries of the shareholders. }\end{array}$ \\
\hline
\end{tabular}

Panel B: Amended Conditions

\begin{tabular}{|l|c|l|c|c|c|}
\hline \multicolumn{1}{|c|}{ Area } & CN & \multicolumn{1}{c|}{$\begin{array}{c}\text { Provision in } \\
\text { CGG-2012 }\end{array}$} & $\begin{array}{l}\text { Change } \\
\text { Made }\end{array}$ & CN & Provision in CGC-2018 \\
\hline $\begin{array}{l}\text { Non-permissible } \\
\text { services for the } \\
\text { external/statutory } \\
\text { auditors }\end{array}$ & $4(\mathrm{vi})$ & $\begin{array}{l}\text { Internal audit } \\
\text { services. }\end{array}$ & Yes & $7(1)(\mathrm{vi})$ & $\begin{array}{l}\text { Internal audit services or special } \\
\text { audit services; }\end{array}$ \\
\hline $\begin{array}{l}\text { Ownership of the } \\
\text { Company being } \\
\text { audited }\end{array}$ & $\begin{array}{l}\text { No direction was } \\
\text { given regarding } \\
\text { ownership by } \\
\text { family members. }\end{array}$ & Yes & $7(2)$ & $\begin{array}{l}\text { Family partner/employees of external } \\
\text { audit firms shall not hold any } \\
\text { shares in the company. Spouse, } \\
\text { son, daughter, father, mother, } \\
\text { brother, sister, son-in-law and } \\
\text { daughter-in-law shall be } \\
\text { considered as family members. }\end{array}$ \\
\hline
\end{tabular}

\subsubsection{Maintaining a Website by the Company}

This head is a new addition to the Code. Previously no such head was there and thus the three conditions under the head are also new (Table 11).

Table 11: New Conditions in Maintaining a Website by the Company.

\begin{tabular}{|c|c|c|c|l|}
\hline \multicolumn{1}{|c|}{ Area } & $\begin{array}{c}\text { Provision in } \\
\text { CGG-2012 }\end{array}$ & $\begin{array}{c}\text { Change } \\
\text { Made }\end{array}$ & CN & \multicolumn{1}{|c|}{ Provision in CGC-2018 } \\
\hline $\begin{array}{l}\text { Maintaining } \\
\text { Company-Website }\end{array}$ & $\begin{array}{c}\text { No such } \\
\text { provision }\end{array}$ & Yes & $8(1)$ & $\begin{array}{l}\text { Company shall have an official website linked } \\
\text { with the stock exchange website. }\end{array}$ \\
\cline { 3 - 5 } & & $8(2)$ & $\begin{array}{l}\text { Company must keep the website functional } \\
\text { from the date of listing. }\end{array}$ \\
\cline { 3 - 5 } & $8(3)$ & $\begin{array}{l}\text { Detailed disclosures as required under the } \\
\text { listing regulations of the stock exchange(s), } \\
\text { shall be made available on company-website. }\end{array}$ \\
\hline
\end{tabular}

4.3.9 Reporting and Compliance of Corporate Governance

There is one new condition (Table 12, Panel A) under the head along with 2 other provisions, of which 1 has been amended (Table 12, Panel B). 
Table 12: Reporting and Compliance of Corporate Governance

Panel A: New Conditions

\begin{tabular}{|l|c|c|c|l|l|}
\hline \multicolumn{1}{|c|}{ Area } & $\begin{array}{c}\text { Provision in } \\
\text { CGG-2012 }\end{array}$ & $\begin{array}{c}\text { Change } \\
\text { Made }\end{array}$ & CN & \multicolumn{3}{|c|}{ Provision in CGC-2018 } \\
\hline $\begin{array}{l}\text { Reporting } \\
\text { and } \\
\text { compliance } \\
\text { of CG }\end{array}$ & $\begin{array}{c}\text { No such } \\
\text { provision }\end{array}$ & Yes & $9(2)$ & $\begin{array}{l}\text { Professional who will provide certificate on } \\
\text { compliance of CGC shall be appointed by the } \\
\text { shareholders in AGM. }\end{array}$ \\
\hline
\end{tabular}

Panel B: Amended Conditions

\begin{tabular}{|c|c|c|c|c|c|}
\hline Area & $\mathbf{C N}$ & Provision in CGG-2012 & $\begin{array}{c}\text { Change } \\
\text { Made }\end{array}$ & $\mathbf{C N}$ & Provision in CGC-2018 \\
\hline $\begin{array}{l}\text { Reporting } \\
\text { and } \\
\text { compliance } \\
\text { of CG }\end{array}$ & 7 (i) & $\begin{array}{l}\text { Company must obtain a } \\
\text { certificate from a } \\
\text { practicing Professional } \\
\text { Accountant/Secretary } \\
\text { (CA/CMA/CS) } \\
\text { regarding compliance of } \\
\text { CGG and shall send the } \\
\text { same to the } \\
\text { shareholders along with } \\
\text { the Annual Report on a } \\
\text { yearly basis. } \\
\text { Meaning of CA, CMA, } \\
\text { CS as per the National } \\
\text { Acts and Laws have been } \\
\text { given as explanation. }\end{array}$ & Yes & $9(1)$ & $\begin{array}{l}\text { Company shall obtain a certificate } \\
\text { from a practicing Professional } \\
\text { Accountant or Secretary } \\
\text { (CA/CMA/CS) other than its } \\
\text { statutory auditors or audit firm } \\
\text { on yearly basis } \\
\text { regarding compliance of CGC and } \\
\text { such certificate shall be disclosed in } \\
\text { the Annual Report. } \\
\text { Meaning of CA, CMA, CS have } \\
\text { been updated as per the National } \\
\text { Acts and Laws, in the explanation. }\end{array}$ \\
\hline
\end{tabular}

\subsubsection{Annexure}

Previously, there was only one annexure but in the CGC 2018, there are three annexures. Two new annexures are titled Annexure-A and Annexure-B whereas the Annexure of CGG-2012 has been modified and titled as Annexure$\mathrm{C}$ in the new code (Table 13).

Table 13: Changes in the Annexure(s).

\begin{tabular}{|c|c|c|c|c|c|}
\hline Annexure & $\begin{array}{c}\text { Reference as } \\
\text { per } \mathrm{CN} \text {. }\end{array}$ & $\begin{array}{l}\text { Required } \\
\text { under CN. }\end{array}$ & CGG-2006 & CGG-2012 & CGC-2018 \\
\hline $\begin{array}{c}\text { Annexure- } \\
\text { A }\end{array}$ & $\begin{array}{l}\text { 1(5)(xxvi) in } \\
\text { CGC } 2018\end{array}$ & $\begin{array}{c}\mathrm{CN}[3(3)] \\
\text { in CGC } \\
2018\end{array}$ & $\begin{array}{c}\text { No such } \\
\text { requirement }\end{array}$ & $\begin{array}{c}\text { No such } \\
\text { requirement }\end{array}$ & $\begin{array}{l}\text { Declaration or certification } \\
\text { on financial statements by } \\
\text { the CEO and the CFO to the } \\
\text { board. } \\
\text { The CEO and CFO must } \\
\text { provide declaration on six } \\
\text { issues and certification on } \\
\text { three issues using } \\
\text { prescribed format and } \\
\text { jointly signing them. }\end{array}$ \\
\hline Annexure-B & $\begin{array}{l}\text { 1(5)(xxvii) in } \\
\text { CGC } 2018\end{array}$ & $\begin{array}{l}\text { CN [9] in } \\
\text { CGC 2018 }\end{array}$ & $\begin{array}{l}\text { No such } \\
\text { requirement }\end{array}$ & $\begin{array}{c}\text { No such } \\
\text { requirement }\end{array}$ & $\begin{array}{l}\text { A report to the shareholders } \\
\text { of the client company } \\
\text { regarding compliance of } \\
\text { conditions of CGC. This is a } \\
\text { new addition, as previously }\end{array}$ \\
\hline
\end{tabular}




\begin{tabular}{|c|c|c|c|c|c|}
\hline & & & & & $\begin{array}{l}\text { there was no prescribed } \\
\text { format of compliance } \\
\text { certificate by professional } \\
\text { CA, CMA or CS. }\end{array}$ \\
\hline Annexure-C & $\begin{array}{l}\text { 1(5)(xxvii) in } \\
\text { CGC } 2018\end{array}$ & $\begin{array}{l}\mathrm{CN} \text { [9] in } \\
\mathrm{CGC} 2018 ; \\
\mathrm{CN} \text { [7] in } \\
\mathrm{CGG} \mathrm{2012;} \\
\mathrm{CN}[5] \text { in } \\
\mathrm{CGG} \mathrm{2006;}\end{array}$ & $\begin{array}{c}\text { A } \\
\text { compliance } \\
\text { checklist of } \\
37 \\
\text { conditions } \\
\text { of CGG } \\
2006 .\end{array}$ & $\begin{array}{c}\text { A } \\
\text { compliance } \\
\text { checklist of } \\
95 \\
\text { conditions } \\
\text { of CGG } \\
2012 .\end{array}$ & $\begin{array}{c}\text { A compliance checklist of } \\
166 \text { conditions of CGC } \\
2018 .\end{array}$ \\
\hline
\end{tabular}

\section{Areas requiring further improvement and inclusion in the Code}

Even after three stages of development of the corporate governance guideline, each at an interval of every six years, there still remain some areas where further improvements can be done. Also, there are some areas that are still excluded from the best-practices recommendations.

There is dearth of provisions regarding risk governance. In CGG 2006, there was no provision addressing risk at all. However, in CGG 2012, there was a provision of an additional statement of 'risk and concerns' in the director's report to shareholders. Later in CGC 2018, the provision was enhanced by adding '...internal and external risk factors, threat to sustainability and negative impact on environment...' [CN. 1(5)(iii)] along with a new provision, requiring the mitigation plan of risk and concern of the company to be included in the Management's Discussion and Analysis section of the Annual Report [CN. 1(5)(xxv)(f)]. Despite these, there is still no precise provision requiring disclosure on risk types, risk quantification, the assessment and management of risk, risk tolerance limit and so on. Although, Bangladesh Bank (BB), the central bank of the country, issued risk management guidelines for banks and other financial institutions with detailed risk management and mitigation plan, there is lack of such prescriptions in the Corporate Governance Code. Consequently, non-financial listed companies are not bound to address various risk issues at all. In absence of industry-specific regulatory practices, the BSEC can devise a comprehensive risk governance guideline, within the $\mathrm{CGC}$, to reflect on the risks and concerns faced by listed companies. In the draft CGC of 2017 (Published in the BSEC website on 21 December, 2017), among many issues, 'risk' was addressed with great importance as seen by the prescription of establishing Risk Management Committee (RMC) but it did not come into being in the final CGC, 2018.

In another context, the quantity of Independent Directors (ID) enhanced from CGG 2006 to CGG 2012. In CGC 2018 , the number remains unchanged but the issue of true independence of the directors' can still be questioned. As most of the companies in Bangladesh are family controlled and, in many cases, the independent directors come from the Old Boy Network of the serving firm, the true independence can still be compromised (Chowdhury, 2019). Again, in Bangladesh, the minimum required number of independent directors in the BoD and other subcommittees of the board is less than the same in the BoD and other sub-committees of other Asian countries. In the BoD, the composition is as follows: (i) India-At least $1 / 3^{\text {rd }}$ of the total board when chairman is a non-executive or at least half of the total board when chairman is a regular executive director; (ii) Pakistan- Higher of 2 or $1 / 3^{\text {rd }}$ of the board; (iii) Malaysia- At least half of the board but for large companies' majority of the board (Securities and Exchange Board of India, 2015; Securities Commission Malaysia, 2017; Securities and Exchange Commission of Pakistan, 2019). Improvement can be made in these regards. Annual assessment of the board members including the independent directors can be required to resolve the question of true independence to some extent. Moreover, prior approval of the independent director nominees by the regulator, upon their own assessment, can mitigate the old boy network problem.

Although, the current CGC enforces the separation of Chairman and CEO/MD, in the Bangladeshi context, for most of the companies, these two positions are occupied by close family members or people with close ties. So, compliance to the provision could be in letter rather than in spirit.

The extant CGC in Bangladesh lacks focus on female participation on the BoD. Female directorship in the BoD was proposed through the 2017 draft but have not been included yet. Since the Bangladesh government emphasizes greatly on women empowerment, CGC could have specific provisions for female representation in the board. Bringing such gender diversity is seen the governance codes of India, Pakistan and Malaysia. Besides, in the governance codes of India and Pakistan, precise requirements of Directors' Training Program are found. 
Bangladeshi code could also follow that path in order to foster greater board effectiveness.

Any provisions outlining the Tax Management and Reporting issues of the companies are still something to look for in the future developments of the Code. To optimize the efficacy of the Audit Committee, it is required that all the Audit Committee members possess sound accounting and financial management background, but the current provision gives leeway through the loosely defined term 'financial literacy'. Yearly evaluation of the board's performance and independence of IDs will nurture board effectiveness and good governance.

According to Malaysian Code on Corporate Governance (MCCG), variation in applying corporate governance code for small and large companies, unlike Bangladesh's current CGC, can reduce cost and bring some flexibility to the small firms (Securities Commission Malaysia, 2017). Bangladesh can follow this practice for its companies as well. The CGC issued by the BSEC targets only the listed companies but it should encourage the non-listed companies like many State-owned Enterprises (SOE), Small and Medium Enterprises (SME) and NonGovernmental Organizations (NGO) to follow CGC in order to enhance accountability, transparency and sustainability. Moreover, portion of the Code could be implemented on 'Comply Basis' whereas some other portions could be implemented on 'Comply or Explain' basis. This would open the avenue for introducing new areas into the code for better governance.

Besides working on these areas, some other areas that could be introduced in the Corporate Governance Code of Bangladesh includes- formation of Executive Committee and Stakeholders Relationship Committee; environmental and social policies, furnishing financial information using XBRL (eXtensible Business Reporting Language), whistle blowing \& security provisions or vigil mechanisms, outline of the BSEC's role in evaluating compliance of $\mathrm{CGC}$ and enforcing repercussions, rewarding and punitive measures as per the governance performance etc.

\section{Conclusion}

Corporate Governance is a control mechanism to lessen agency problem and thereby fostering fairness, transparency, accountability and responsibility in the corporate culture. A decent and comprehensive corporate governance code can promote better practices and its proper exercise can attract both local and overseas investors, lenders and other stakeholders by facilitating their convictions. Hence, CG guidelines were refurbished twice after its first decree to extend its scope for good governance. Many changes have come over the years. In the recent development, the addition of Nomination and Remuneration Committee (NRC) is the most exigent composition that covers several directions. Still the provisions regarding NRC have room for improvement. On the other hand, maintaining company website is another crucial composition in the new code that can pull more trust of investors, lenders and other interested parties. Even after considering all these, it is a fact that the first Code of CG in Bangladesh, with voluntary requirements by a private initiative (BEI, 2004) was more comprehensive and coherent with the CG guide of UN than the CGG 2006 by SEC (Qurashi, 2018). Then again, many important aspects of good governance included in BEI's Code of CG are still not covered in the current CGC 2018. Consequently, the regulatory authority should focus on sustainable development of CGC considering the best CG practices exercised all over the world, especially our neighboring countries, rather than routine minute reformation of the code. As the CGC 2018 has been newly enacted in June, 2018 there have been very few works on it and thus- comparison with neighboring countries' CGC, checking the coherence with CG guide of UN and OECD and other best practices, as well as implementation of the new CGC 2018 across different industries in Bangladesh and its impact on firm performance and disclosure etc. might be studied and investigated in the coming days.

\section{References}

Aguilera, R. and Cuervo-Cazurra, A., 2004. Codes of Good Governance Worldwide: What is the Trigger?. Organization Studies, [online] 25(3), pp.415-443. Available at: $<\mathrm{http}: / /$ citeseerx.ist.psu.edu/viewdoc/download?doi=10.1.1.196.3301\&rep=rep1\&type=pdf $>$.

Bangladesh Enterprise Institute. 2003. A Comparative Analysis Of Corporate Governance In South Asia: Charting A Roadmap For Bangladesh. [online] Available at: <https://bei-bd.org/publications/a-comparative-analysisof-corporate-governance-in-south-asia-charting-a-roadmap-for-bangladesh/>.

Bangladesh Enterprise Institute. 2004. The Code Of Corporate Governance For Bangladesh. [online] Available at: $<$ https://bei-bd.org/publications/the-code-of-corporate-governance-for-bangladesh/>. 
Bangladesh Securities and Exchange Commission (BSEC), 2018. Corporate Governance Code. Dhaka: Bangladesh Securities and Exchange Commission, pp.6872-6902.

Bhowmik, S. and Islam, M., 2013. Comparative Analysis of Corporate Governance Guidelines in Asian Countries. The Cost and Management, [online] 41(4), pp.41-47. Available at: $<$ https://www.academia.edu/14524741/Comparative_Analysis_of_Corporate_Governance_Guidelines_in_ Asian_Countries>.

Biswas, P., 2012. Corporate Governance Guidelines in Bangladesh: Some Observations. The Cost and Management, [online] XL(4). Available at: $<\mathrm{http}: / /$ ssrn.com/abstract=2271156>.

Chowdhury, D., 2019. Incentives, Control And Development: Governance In Private And Public Sector With Special Reference To Bangladesh. 3rd ed. Dhaka: Dhaka University Prakashana Sangstha, pp.162, 168-170.

Das, S., Das, S. and Das, M., 2018. Comparative Study of Corporate Governance Guidelines in SAARC Countries. European Journal of Business and Management, [online] 10(26). Available at: $<$ https://www.researchgate.net/publication/328065966>.

Gillibrand, M., 2004. Corporate management essential for industrialization. The Bangladesh Observer,.

Qurashi, M., 2018. Corporate Governance Code Comparison for South Asian Emerging Economies. International Journal of Law and Management, [online] 60(2), pp.250-266. Available at: $<$ https://doi.org/10.1108/ijlma05-2017-0115>.

Rahman, M. and Khatun, N., 2017. A Comparative Analysis of Corporate Governance Guidelines: Bangladesh Perspective. The East Asian Journal of Business Management, [online] 7(2), pp.5-16. Available at: $<$ https://doi.org/10.13106/eajbm.2017.vol7.no2.5>.

Securities and Exchange Board of India, 2015. Securities And Exchange Board Of India (Listing Obligations And Disclosure Requirements). New Delhi: Authority New Delhi.

Securities and Exchange Commission (SEC), 2006. Corporate Governance Guidelines. Dhaka: Securities and Exchange Commission.

Securities and Exchange Commission (SEC), 2012. Corporate Governance Guidelines. Dhaka: Securities and Exchange Commission.

Securities and Exchange Commission of Pakistan, 2019. The Listed Companies (Code Of Corporate Governance). Islamabad: Securities and Exchange Commission of Pakistan.

Suruhanjaya Sekuriti Securities Commission Malaysia, 2017. Malaysian Code On Corporate Governance. Kuala Lumpur: Suruhanjaya Sekuriti Securities Commission Malaysia. 